\title{
Indications for Implant Removal after Fracture Healing a review of literature
}

\author{
Dagmar I. Vos, Michael H.J. Verhofstad
}

Keywords Implant removal. Hardware removal . Metal implants . Osteosynthesis . Fracture healing . Indications

\section{I. Vos ( $\square)$}

Orthopedic trauma surgeon. Department of Surgery, Amphia Hospital Breda, PO Box 90158, 4800 RK Breda, the Netherlands

Telephone: + 3176595 1146; Fax: + 31765953818

E-mail: dvos@amphia.nl

\section{M.H.J. Verhofstad}

Orthopedic trauma surgeon. Head of department of Trauma Surgery, Erasmus University Medical Centre, PO Box 2040, 3000 CA Rotterdam, the Netherlands 


\begin{abstract}
Introduction The aim of this review was to collect and summarize published data on the indications for implant removal after fracture healing since these are not well defined and guidelines hardly exist.

Methods A literature search was performed.

Results Though there are several presumed benefits of implant removal, like functional improvement and pain relief, the surgical procedure can be very challenging and may lead to complications or even worsening of the complaints. Research has focused on the safety of metal implants (e.g. risk of corrosion, allergy and carcinogenesis). For these reasons implants have been removed routinely for decades. Along with the introduction of titanium alloy implants, the need for implant removal became subject of debate in view of potential (dis)advantages since in general, implants made of titanium alloys are more difficult to remove. Currently, the main indications for removal from both the upper and lower extremity are mostly 'relative' and patient driven like pain, prominent material or just the request for removal. True medical indications like infection or intra-articular material are minor reasons.

Conclusion This review illustrates the great variety of view points with large differences in opinions and practices about the indications for implant removal after fracture healing. Since some studies have described asymptomatic patients developing complaints after removal, the general advise nowadays is to remove implants after fracture healing only in symptomatic patients and after a proper informed consent. Well designed prospective studies on this subject are urgently needed to make guidelines based on scientific evidence.
\end{abstract}




\section{Introduction}

The different options for operative fracture treatment using metal implants have increased substantially the last decade. Worldwide metal implants (e.g. plates, screws and nails) are used which are generally made of stainless steel or titanium alloys. After fracture healing has taken place an implant no longer has any function and the question rises whether the implant should be removed and if so, why and when? Though there are several presumed benefits of implant removal, like functional improvement and pain relief, the surgical procedure can be very challenging and may lead to complications such as neurovascular injury and refractures, whereas the expected outcome is not well determined yet. The (medical) indications for surgical removal of these metal implants are not well defined and a variety of view points with large differences in opinions and practices between surgeons, countries, patients, anatomical locations and implant materials exist [1-6]. There is a lack of clear guidelines concerning implant removal, only in Germany a more or less consensus based guideline exists [7]. In this review of literature the indications for implant removal after fracture healing are discussed. Implant removal in children will be discussed elsewhere in this journal. 


\section{Methods}

A Pubmed MEDLINE, Embase, Web of Science and Cochrane Library database search has been performed on all literature dealing with the indications for implant removal after healing of long bone fractures from the early sixties of the last century until january 2013 with at least an english abstract. The search strategy used was $(((()((()(($ device $)$ OR implant) OR hardware) OR metal) OR orthopaedic) OR orthopedic) OR osteosynthesis)) AND (fracture)) AND (((removal) OR remove) OR extraction)) NOT (((dent*) OR maxil*) OR mandib*)) NOT ((prosthe*) OR arthroplast*)) NOT ((thorac*) OR lumb*). This search strategy revealed 2164 hits. All titles and abstracts have been screened by the first author (DIV) for relevance. Literature on removal of prosthesis, implants from the maxillofacial and spine area and positioning screws of the ankle were excluded. Sixty-seven articles were considered eligible for use in this review. Full paper versions were obtained, read and subsequently searched for cross references. The majority of these articles were retrospective case series.

For a structured overview of various subjects concerning the indications for implant removal after fracture healing, the literature was used to answer the following questions: 'Do implants need to be removed because they damage health?', 'What are the current indications and pratices for implant removal after fracture healing?', 'What are the specific indications for implant removal from the upper extremity?' and 'What are the specific indications for implant removal from the lower extremity?' 


\section{Do implants need to be removed because they damage health?}

Since World War II treatment of fractures has shifted from a nonoperative fashion towards an operative therapy using metal implants (e.g. plates, screws and nails). These implants used to be made of stainless steel, an alloy of chrome, nickel and molybdenum and much research focused on finding an optimal alloy for fracture treatment with the best biocompatibility. The alloy had to be strong enough, non-corrosive, non-carcinogenic, infection resistant and tolerated by the immune system.

For many years the potential risk of corrosion has been an indication for many surgeons to remove implants routinely after fracture healing. This process of oxidation of metal leads to loosening of small particles that can be biologically active. Such particles can lead to an inflammatory tissue reaction with the formation of necrosis, granulation and fibrous tissue. Most research on these aspects goes back to the seventies and eighties of the last century [8,9]. Implants made of stainless steel produce corrosion in symptomatic and asymptomatic patients, but the clinical significance remained unclear [10]. Along with the problem of corrosion, metal implants were also considered to play a role in the genesis of cancer. However, several experimental studies could not reveal any association between metal implants and the development of any form of cancer [11]. Since the nineties corrosion and cancer were no longer considered to be an indication for standard removal anymore.

Allergic reactions to implants made of stainless steel, leading to skin changes, eczema, delayed wound healing, pain or even implant loosening (not to be mixed up with symptoms caused by a low grade infection), have been described and were another indication for routine removal. But in contrast to the high incidence of cutaneous metal contact allergy (e.g. nickel), allergies associated with internal devices are rare and epidemiological data on implant-related allergic reactions scarce $[12,13]$.

Also bone atrophy has been an argument for implant removal [14, 15]. Rosson et al published two detailed studies about the influence of plates to the underlying bone structure. Cortical bone atrophy was found in one patient in whom a plate of 
the forearm was removed after 16 months. In 14 other patients, who had their forearm plates removed in a much later stage, the bone density had returned to its pre-fracture level. In young adults the bone mass at the site of residual holes after screw removal returned close to normal after 18 weeks $[16,17]$. Therefore, in order to reduce the risk for a refracture, it was recommended to leave plates in for at least 21 months or not to remove them at all.

New generation metal implants are alloys of titanium, aluminum and niobium (TAN; Synthes ${ }^{\circledR}$ ) or titanium, aluminum and vanadium (Stryker ${ }^{\circledR}$ ). After the introduction of TAN in 1977 its composition has been improved continuously. The biocompatibility of TAN is excellent and so far no toxic reactions, signs of corrosion or allergic reactions have been described, which has made its use rather popular the last 15 years [18-20]. But since the widespread use of locked head TAN plates, technical difficulties during removal have become a new problem [21]. Removal of TAN implants can be extremely difficult due to screwhead locking into the plate or bone overgrowth at the implant surface. Richards et al described that not only the composition of the alloy, but also its surface structure matters in these cases [22-26].

Next to the lack of proof that implants damage health, the observed technical problems have made surgeons less enthusiastic to remove implants after fracture healing. But what to do with patients with complaints attributed to the implant? 


\section{What are the current indications for and pratices of implant removal after fracture healing?}

The growing amount of arguments against routine implant removal, justify a reevaluation of the existing 'absolute' and 'relative' indications for removal, since implant removal after fracture healing requires at least a new operation, the results are unpredictable and the procedure can be very frustrating; "Attempts at hardware removal are often frustrating events, resulting in broken implants and retrieval equipment, prolonged surgical times and frustrated, humbled surgeons" (citation James Kellam, Carolinas Medical Center, Charlotte, NC USA).

Minimal invasive plate osteosyntheses or intramedullary nailing can lead to 'maximal invasive' implant removal procedures with surgery related risks like bleeding, wound infection, nerve injury, refracture, a poor cosmetic result and the risk for anesthesiology related adverse events. All these drawbacks come with large costs and potential social consequences and are arguments against removal (Table 1).

In 1992 Sanderson et al described an overall complication rate of $20 \%$ in 188 patients who had their metal implants removed [27]. In forearm plate removal they even observed $42 \%$ complications. Instead in another prospective study, presenting the results of 86 adult patients who had their implant removed, 46 patients had been somehow symptomatic at the time of removal. A good clinical outcome was achieved in $91 \%$ of the symptomatic patients and no problems were seen in $95 \%$ of the asymptomatic cases. The overall complication rate was $3 \%$, including a radial nerve injury and a refracture. It was concluded that in asymptomatic patients it might be appropriate to leave implants [28]. Minkowitz et al published a prospective study of 60 patients (57 with a complete follow up of one year) with pain in the region of their fixed and healed fracture in order to evaluate the outcome after implant removal [29]. Surgery related complications were not described. The overall improvement of function and pain one year after implant removal was significant $(p=0.00001)$. All patients were satisfied and if necessary would undergo the removal procedure again. 
In an overview published in 2003 about the indications for and risks of implant removal after osteosynthesis, implants clearly interfering with surrounding tissues and function and implants in growing individuals were defined as absolute indications for removal [30]. Mild implant related tissue reactions were considered to be debatable indications.

Currently the indications in favour of implant removal are mostly 'relative' [31]. The absolute indications for implant removal nowadays only include perforating material (e.g. K-wires or external fixators). Even implant removal in the growing skeleton has become controversial and is no longer considered an absolute indication anymore. No evidence that supports routine implant removal in children can be found [3, 32-34]. Also infection after operative fracture treatment is not always an absolute indication for removal. On the contrary, maintenance of fracture stabilization is mandatory to treat the infection. In most cases the hardware can be left in situ until the fracture has healed. Operative wound débridement, local and systemic antibiotic therapy and retention of the hardware has proven to be a succesfull concept [35-38].

However, after internal osteosynthesis many patients experience complaints and symptoms like pain, discomfort, soft tissue compression, swelling and stifness of the previously fractured limb. Whether these problems are really due to the implant or exist anyway because of the injury, subsequent surgery and the healed fracture with resulting scar tissue is often unclear. Also the reason 'the implant doesn't belong in my body' and 'I simply want to get it out' can be a relative indication for removal. Possible future problems like metal implants behaving as a stress riser resulting in peri-implant fractures or the future need for a joint replacement because of osteoartrosis can be a 'relative' indication for implant removal after fracture healing. No literature exists that supports these potential indications.

Four 'large' surveys on current practices and different aspects of implant removal have been published so far. In 2008 a survey on implant removal was performed by Jamil et al in the United Kingdom [6]. Goal of this survey was to determine the current practice of orthopaedic surgeons regarding implant removal after healed 
limb fractures. Routine removal in patients under the age of 16 years was advocated by $60 \%$, in the age of $16-35$ years by $12 \%$ and in patients older than 35 years by only $3 \%$ of the surgeons. Indications for implant removal in symptomatic patients were pain, implant loosening, infection, broken implants, skin irritation, peri-prosthetic fractures and functional limitation. Only $7 \%$ of the respondents had some kind of guideline on implant removal available in their hospital. Hanson et al published a survey under 730 participants of the 2007 AO courses on operative fracture treatment in Davos [1]. It contained questions about general beliefs and reasons for implant removal. With a response rate of almost $90 \%, 58 \%$ of the participants did not advocate routine removal and $48 \%$ believed that in general it is more risky to take the implant out than leaving it in. In symptomatic patients implant removal was rated more effective, though orthopaedic surgeons were less enthusiastic than trauma surgeons in doing so. Loder and Feinberg presented the opinion of 273 pediatric and 99 non-pediatric orthopaedic surgeons in the United States about routine removal of orthopaedic implants in children [3]. Forty-one percent of the surgeons were in favour of implant removal in general even if the child had no related complaints, 36\% removed "sometimes" and 22\% (almost) never removed implants in children. The more experienced and elderly surgeons, regardless of their background, were in favour of routine implant removal in children in general because of their experience with potential future problems.

Though implant removal is not routinely performed in the Netherlands, in our own survey under 250 Dutch surgeons, $89 \%$ agreed that implant removal is a good option in case of pain or functional deficits. Also infection of the implant or bone was one of the main reasons for removal ( $>90 \%)$. In younger patients $(<40$ years of age) only $34 \%$ of the surgeons agreed that metal implants should always be removed [39]. 


\section{What are the specific indications for implant removal from the upper extremity?}

Complaints of the patient (e.g. pain, prominent material, cosmetically disturbing material, functional impairment) are the main reasons for implant removal from the upper extremity, but evidence based literature about the expected improvement of these complaints hardly exists. Ten studies about implant removal from the upper extremity could be found. All were retrospective, didn't deal specifically about the indications and - except for two studies - were mostly published 20-30 years ago (Table 2). These older studies mainly focussed on complications like refractures after removal of ulna and radius plates. Complication rates between 19 and 26\% were described. Protective splints and prevention of torsional stress and/or contact sports up to one year after the removal were advised [40, 41]. In studies published in the nineties 4-6\% refractures were reported $[42,43]$. All studies have contributed to the recommendation that due to the high numbers of complications forearm plates should be left in situ in asymptomatic patients [44, 45]. Moreover it was advised that only experienced surgeons should perform implant removal surgery [46]. In other areas of the arm, literature is scarce. Very recently Gyuricza et al described the effects of removal of locked volar plates in a retrospective series of 28 patients after a distal radius fracture [47]. Reasons for removal included tenosynovitis, tendon rupture, prominent or intra-articular material and pain. Apart from two implant related complications all plates were succesfully removed and preoperative complaints improved. Lovald published the results of a nationwide study about hardware removal after internal fixation of humeral fractures [48]. Hardware removal is not part of standard care in the United States and implant removal from the humerus only was performed in case of complications like nonunion, mechanical problems and infection (10\%). Older patients were more likely to undergo the procedure than younger ones, whereas self-pay patients were less likely to have their humerus implant removed. 


\section{What are the specific indications for implant removal from the lower extremity?}

A limited number of publications $(n=13)$ on removal of intramedullary femur and tibia nails exist, all adressing different issues (Table 3a\&b). Retrospective studies analysing patients who had their femur nail removed, describe indications as soft tissue irritation, patient's request, pain in hip and knee region, infection or no specific indication. No differences between titanium and stainless steel nails could be found with regard to complications of removal. Though pain seemed to decrease in all symptomatic patients, the advise was only to remove femur nails in symptomatic patients [49-53]. Gösling et al showed, in a retrospective study analysing the removal of 164 femoral nails after fracture healing, that $78 \%$ of the patients with existing local complaints improved postoperatively [54]. However, 10 out of 51 patients who were asymptomatic preoperatively reported long-term complaints after removal. Therefore they advised to remove femur nails only in symptomatic patients. Apart from these clinical complaints and symptoms it has been described that femoral nails are more often removed in patients with litigations [55].

Indications for removal of various proximal femur implants (e.g. sliding hip screw and cephalocondylic intramedullary nail systems) have been described by Kukla et al [56]. Absolute indications for removal were considered avascular necrosis of the femur head, deep infection, a fracture just below the implant and a cephalic cut out of the implant. Removal of cephalocondylic nails in patients younger than 60 years, was also seen as a more or less absolute indication, because of the risk for ipsilateral shaft fractures distal to the implant. But in all other cases they advised to inform the patient about the disbalance between potential advantages and complications prior to removal. Krettek and Mommsen described a similar advise in their review [57].

Out of these 13 articles six articles analysed the effect of removal of tibia nails. Anterior knee pain is among the most frequent complaints after tibia nailing and a main indication for removal. Keating et al, Karladani et al and Boerger et al found 
that approximately half of the patients with anterior knee pain benefit from nail removal $(22 / 49,40 / 75$ and 9/16 respectively) $[49,58,59]$. However, in the latter study 4/16 asymptomatic patients developed anterior knee pain after nail removal. Recent studies suggest that anterior knee pain might result from other causes, such as iatrogenic infrapatellar nerve injury and this problem will not be solved by extraction of the nail, but can even induce such complaints [60]. Improvement of other symptoms was described in $72 \%$ of the patients, but up to $17 \%$ of the preoperatively asymptomatic patients reported (new) long-term complaints at follow up [61, 62]. Complications during tibia nail removal merely exist from failures to extract the implant and iatrogenic fractures [63, 64]. All authors stated that routine removal is not indicated and should be appraised critically in asymptomatic patients.

Publications on the outcome of removal of proximal, midshaft or distal femur or tibia plates hardly exist. A retrospective study, published in 2001, evaluated pain improvement in the distal tibia and fibula area after implant removal of unstable ankle fractures. Although in the group of 29 patients pain in general decreased, nearly half of them persisted having pain and functional outcome scores (Short Form-36 Health Survey and Short Form Musculoskeletal Functional Assessment) seemed to be independent of implant removal [65]. Benefits of implant removal from the foot and ankle were described in a prospective study of 69 patients who underwent elective removal of symptomatic implants. Pain relief and a high rate of patient satisfaction $91 \%$ were described [66]. 


\section{Discussion}

Indications for implant removal after fracture healing are diverse and hardly supported by literature since most publications are retrospective studies, case reports and expert opinion (evidence level III, IV or V). It remains clear that there is no worldwide consensus. Opinions and habits not only vary between surgeon related factors (e.g. differences between countries), but also patient related factors (e.g. differences between children and adults, anatomical locations) and implant related factors (e.g. stainless steel versus titanium alloys). Even the ability of the patient to pay for implant removal surgery or accident related litigations seem to be of influence in the decision making.

Each operation has its costs, implies a recovery period and temporary unability to work with possible social consequences. In Scandinavia implant removal accounts for $15 \%$ of all operations in the orthopaedic and trauma unit, in comparison to less than $5 \%$ in the United States. Two Scandinavian studies investigating the workload related to implant removal, concluded that without a strict removal policy a considerable portion of the resources allocated for elective orthopaedic operations was spent on routine and possibly unnecessary implant removal. Therefore more evidence based research will be necessary to support the indications for implant removal.

Currently most indications for removal are 'relative' meaning they are not really necessary and often are driven by patients complaints and symptoms. Pain, functional impairment, prominent material, possible future problems and the patients' request are the main examples of 'relative' indications for removal. 'Absolute' indications for removal are avascular necrosis of the femur head, deep infection and the cut out of an implant. Corrosion and the possible role of metal implants in the genesis of cancer are no longer accepted reasons for removal. Surgeons and patients are more aware of the appropriate indications for and expectations of the risks and benefits of implant removal. Improvement of complaints after removal is debatable and disadvantages, like surgery related complications or even worsening of the complaints can appear and are important reasons for the antagonists of removal to leave the implant in $[27,28,30,67]$. In 
general the complication rate differs significantly between studies and estimated risks for adverse events vary from 0 to $1 \%$ for postoperative hematoma, up to $14 \%$ for wound infection, 1 to $29 \%$ for nerve injury, 1 to $30 \%$ for a refracture and up to $9 \%$ for obtaining a cosmetically disturbing scar [27, 28, 40-42, 44-46, 68]. However, in symptomatic patients the disadvantages are accepted to give these patients the benefit of the doubt, as one of the potential advantages of implant removal might be improvement of complaints. On the other hand in asymptomatic patients it is accepted to leave the implant in.

Operative fracture treatment and subsequent implant removal from the upper extremity differs from the lower extremity because bones are smaller and do not bear body weight, more plates than nails are used, the risk of disabilitating nerve injury is higher (e.g. radial nerve at humerus shaft) and scars are more exposed. Instead most of the indications for removal (e.g. pain, functional impairment) are not very different between extremities. The fear for refractures after implant removal used to play an important role in the upper extremity, since refractures after proper healing are hardly seen in the lower extremity. But along with the shift from routine removal to removal in symptomatic patients only, the number of refractures seems to have decreased during the past years.

Though a removal procedure can be very challenging and make surgeons humble, symptomatic patients do seem to benefit. Since some authors described significant complaints at long-term follow up due to removal in previously asymptomatic patients, the general advise nowadays is to remove implants after fracture healing only in symptomatic patients after a proper informed consent. 


\section{Conclusion}

The overall magnitude of the problem of the indications for implant removal after fracture healing is illustrated by the great variety of reported view points with large differences in opinions and practices between surgeons, countries, patients, extremities and implants. Robust evidence hardly exists in the literature and only a few clear guidelines are formulated so far. With the increasing popularity of operative fracture treatment using metal implants, initially routine implant removal was advised because of the supposed implant related risk of corrosion and carcinogenesis. However, it became clear that these risks were minimal or even nonexistent. Since the introduction of titanium alloys the potential disadvantages of removal plays an important role in the decision making. Currently, indications for removal are mainly 'relative' and patient driven, like in case of complaints of the patient (e.g. pain, prominent material). Although some studies support implant removal in symptomatic patients, well designed prospective studies are urgently needed to make proper guidelines.

\section{Conflict of interest}

The authors declare that they have no conflict of interest 


\section{Literature}

1. Hanson B, van der Werken C, Stengel D. Surgeons' beliefs and perceptions about removal of orthopaedic implants. BMC Musculoskelet Disord. 2008;9:73.

2. Busam ML, Esther RJ, Obremskey WT. Hardware removal: indications and expectations. J Am Acad Orthop Surg. 2006 Feb;14(2):113-20.

3. Loder RT, Feinberg JR. Orthopaedic implants in children: survey results regarding routine removal by the pediatric and nonpediatric specialists. J Pediatr Orthop. 2006 Jul-Aug;26(4):510-9.

4. Bostman O, Pihlajamaki $\mathrm{H}$. Routine implant removal after fracture surgery: a potentially reducible consumer of hospital resources in trauma units. $J$ Trauma. 1996 Nov;41(5):846-9.

5. Molster A, Behring J, Gjerdet NR, Ekeland A. Removal of osteosynthetic implants. Tidsskr Nor Laegeforen. 2002 Sep 30;122(23):2274-6.

6. Jamil W, Allami M, Choudhury MZ, Mann C, Bagga T, Roberts A. Do orthopaedic surgeons need a policy on the removal of metalwork? A descriptive national survey of practicing surgeons in the United Kingdom. Injury. 2008 Mar;39(3):362-7.

7. Available from: www.awmf.org/leitlinien/detail/l//012-004.html

8. Black J. Does corrosion matter? J Bone Joint Surg Br. 1988 Aug;70(4):517-20.

9. Levine DL, Staehle RW. Crevice corrosion in orthopedic implant metals. J Biomed Mater Res. 1977 Jul;11(4):553-61.

10. Thomas KA, Cook SD, Harding AF, Haddad RJ, Jr. Tissue reaction to implant corrosion in 38 internal fixation devices. Orthopedics. 1988 Mar;11(3):441-51.

11. Grogan $\mathrm{CH}$. Experimental studies in metal cancerigenesis. VIII. On the etiological factor in chromate cancer. Cancer. 1957 May-Jun;10(3):625-38.

12. Hallab N, Merritt $\mathrm{K}$, Jacobs JJ. Metal sensitivity in patients with orthopaedic implants. J Bone Joint Surg Am. 2001 Mar;83-A(3):428-36.

13. Thomas $\mathrm{P}$, Thomsen $\mathrm{M}$. [Allergy diagnostics in implant intolerance]. Orthopade. 2008 Feb;37(2):131-5.

14. Muller A, Schneider, editor. Manuel of Internal Fixation. 2nd ed. New York: Springer; 1979.

15. Kettunen J, Kroger H, Bowditch M, Joukainen J, Suomalainen O. Bone mineral density after removal of rigid plates from forearm fractures: preliminary report. J Orthop Sci. 2003;8(6):772-6.

16. Rosson JW, Petley GW, Shearer JR. Bone structure after removal of internal fixation plates. J Bone Joint Surg Br. 1991 Jan;73(1):65-7.

17. Rosson J, Murphy W, Tonge C, Shearer J. Healing of residual screw holes after plate removal. Injury. 1991 Sep;22(5):383-4.

18. du Preez LA, Butow KW, Swart TJ. Implant failure due to titanium hypersensitivity/allergy?--Report of a case. SADJ. 2007 Feb;62(1):22, 4-5.

19. Krischak GD, Gebhard F, Mohr W, Krivan V, Ignatius A, Beck A, et al. Difference in metallic wear distribution released from commercially pure 
titanium compared with stainless steel plates. Arch Orthop Trauma Surg. 2004 Mar;124(2):104-13.

20. Serhan $H$, Slivka M, Albert T, Kwak SD. Is galvanic corrosion between titanium alloy and stainless steel spinal implants a clinical concern? Spine J. 2004 Jul-Aug;4(4):379-87.

21. Ehlinger $M$, Adam $\mathrm{P}$, Simon $\mathrm{P}$, Bonnomet $\mathrm{F}$. Technical difficulties in hardware removal in titanium compression plates with locking screws. Orthop Traumatol Surg Res. 2009 Sep;95(5):373-6.

22. Richards RG. The effect of surface roughness on fibroblast adhesion in vitro. Injury. 1996;27 Suppl 3:SC38-43.

23. Meredith DO, Riehle MO, Curtis AS, Richards RG. Is surface chemical composition important for orthopaedic implant materials? J Mater Sci Mater Med. 2007 Feb;18(2):405-13.

24. Hayes JS, Seidenglanz U, Pearce AI, Pearce SG, Archer CW, Richards RG. Surface polishing positively influences ease of plate and screw removal. Eur Cell Mater. 2010;19:117-26.

25. Pearce Al, Pearce SG, Schwieger K, Milz S, Schneider E, Archer CW, et al. Effect of surface topography on removal of cortical bone screws in a novel sheep model. J Orthop Res. 2008 Oct;26(10):1377-83.

26. Hayes JS, Vos DI, Hahn J, Pearce SG, Richards RG. An in vivo evaluation of surface polishing of TAN intermedullary nails for ease of removal. Eur Cell Mater. 2009;18:15-26.

27. Sanderson PL, Ryan W, Turner PG. Complications of metalwork removal. Injury. 1992;23(1):29-30.

28. Richards RH, Palmer JD, Clarke NM. Observations on removal of metal implants. Injury. 1992;23(1):25-8.

29. Minkowitz RB, Bhadsavle S, Walsh M, Egol KA. Removal of painful orthopaedic implants after fracture union. J Bone Joint Surg Am. 2007 Sep;89(9):1906-12.

30. Muller-Farber J. [Metal removal after osteosyntheses. Indications and risks]. Orthopade. 2003 Nov;32(11):1039-57; quiz 58.

31. Krettek C, Muller C, Meller R, Jagodzinski M, Hildebrand F, Gaulke R. Is routine implant removal after trauma surgery sensible?. Unfallchirurg. 2012 Apr;115(4):315-22.

32. Raney EM, Freccero DM, Dolan LA, Lighter DE, Fillman RR, Chambers HG. Evidence-based analysis of removal of orthopaedic implants in the pediatric population. J Pediatr Orthop. 2008 Oct-Nov;28(7):701-4.

33. Morshed S, Humphrey M, Corrales LA, Millett M, Hoffinger SA. Retention of flexible intramedullary nails following treatment of pediatric femur fractures. Arch Orthop Trauma Surg. 2007 Sep;127(7):509-14.

34. Gorter EA, Vos DI, Sier CF, Schipper IB. Implant removal associated complications in children with limb fractures due to trauma. Eur J Trauma Emerg Surg. 2011 Dec;37(6):623-7.

35. Berkes M, Obremskey WT, Scannell B, Ellington JK, Hymes RA, Bosse M. Maintenance of hardware after early postoperative infection following fracture internal fixation. J Bone Joint Surg Am. 2010 Apr;92(4):823-8. 
36. Rightmire E, Zurakowski D, Vrahas M. Acute infections after fracture repair: management with hardware in place. Clin Orthop Relat Res. 2008 Feb;466(2):466-72.

37. Trampuz A, Widmer AF. Infections associated with orthopedic implants. Curr Opin Infect Dis. 2006 Aug;19(4):349-56.

38. Trampuz A, Zimmerli W. Diagnosis and treatment of infections associated with fracture-fixation devices. Injury. 2006 May;37 Suppl 2:S59-66.

39. Vos D, Hanson B, Verhofstad M. Implant removal of osteosynthesis: the Dutch practice. Results of a survey. J Trauma Manag Outcomes. 2012;6(1):6.

40. Hidaka S, Gustilo RB. Refracture of bones of the forearm after plate removal. J Bone Joint Surg Am. 1984 Oct;66(8):1241-3.

41. Deluca PA, Lindsey RW, Ruwe PA. Refracture of bones of the forearm after the removal of compression plates. J Bone Joint Surg Am. 1988 Oct;70(9):1372-6.

42. Rumball K, Finnegan M. Refractures after forearm plate removal. J Orthop Trauma. 1990;4(2):124-9.

43. Labosky DA, Cermak MB, Waggy CA. Forearm fracture plates: to remove or not to remove. J Hand Surg Am. 1990 Mar;15(2):294-301.

44. Langkamer VG, Ackroyd CE. Removal of forearm plates. A review of the complications. J Bone Joint Surg Br. 1990 Jul;72(4):601-4.

45. Rosson JW, Shearer JR. Refracture after the removal of plates from the forearm. An avoidable complication. J Bone Joint Surg Br. 1991 May;73(3):415-7.

46. Chia J, Soh CR, Wong HP, Low YP. Complications following metal removal: a follow-up of surgically treated forearm fractures. Singapore Med J. 1996 Jun;37(3):268-9.

47. Gyuricza C, Carlson MG, Weiland AJ, Wolfe SW, Hotchkiss RN, Daluiski A. Removal of locked volar plates after distal radius fractures. J Hand Surg Am. 2011 Jun;36(6):982-5.

48. Lovald S, Mercer D, Hanson J, Cowgill I, Erdman M, Robinson P, et al. Complications and hardware removal after open reduction and internal fixation of humeral fractures. J Trauma. 2011 May;70(5):1273-7; discussion 7-8.

49. Boerger TO, Patel G, Murphy JP. Is routine removal of intramedullary nails justified. Injury. 1999 Mar;30(2):79-81.

50. Husain A, Pollak AN, Moehring HD, Olson SA, Chapman MW. Removal of intramedullary nails from the femur: a review of 45 cases. J Orthop Trauma. 1996;10(8):560-2.

51. Brumback RJ, Ellison TS, Poka A, Bathon GH, Burgess AR. Intramedullary nailing of femoral shaft fractures. Part III: Long-term effects of static interlocking fixation. J Bone Joint Surg Am. 1992 Jan;74(1):10612.

52. Toms AD, Morgan-Jones RL, Spencer-Jones R. Intramedullary femoral nailing: removing the nail improves subjective outcome. Injury. 2002 Apr;33(3):247-9. 
53. Dodenhoff RM, Dainton JN, Hutchins PM. Proximal thigh pain after femoral nailing. Causes and treatment. J Bone Joint Surg Br. 1997 Sep;79(5):738-41.

54. Gosling T, Hufner T, Hankemeier S, Zelle BA, Muller-Heine A, Krettek C. Femoral nail removal should be restricted in asymptomatic patients. Clin Orthop Relat Res. 2004 Jun(423):222-6.

55. Hui C, Jorgensen I, Buckley R, Fick G. Incidence of intramedullary nail removal after femoral shaft fracture healing. Can J Surg. 2007 Feb;50(1):13-8.

56. Kukla C, Gaebler C, Mousavi M, Vécsei V, Heinz T. Indications for Implant Removal in Healed Proximal Femoral Fractures. Acta Chir Austriaca. 2000;32:196-8.

57. Krettek C, Mommsen P. Implant removal after intramedullary osteosyntheses. Literature review, technical details, and tips and tricks. Unfallchirurg. 2012 Apr;115(4):299-314.

58. Keating JF, Orfaly R, O'Brien PJ. Knee pain after tibial nailing. J Orthop Trauma. 1997 Jan;11(1):10-3.

59. Karladani AH, Ericsson PA, Granhed H, Karlsson L, Nyberg P. Tibial intramedullary nails -- should they be removed? A retrospective study of 71 patients. Acta Orthop. 2007 Oct;78(5):668-71.

60. Leliveld MS, Verhofstad $\mathrm{MH}$. Injury to the infrapatellar branch of the saphenous nerve, a possible cause for anterior knee pain after tibial nailing? Injury. 2011 Sep 29.

61. Sidky A, Buckley RE. Hardware removal after tibial fracture has healed. Can J Surg. 2008 Aug;51(4):263-8.

62. Gosling T, Hufner T, Hankemeier S, Muller U, Richter M, Krettek C. [Indication for removal of tibial nails]. Chirurg. 2005 Aug;76(8):789-94.

63. Im GI, Lee KB. Difficulties in removing ACE tibial intramedullary nail. Int Orthop. 2003;27(6):355-8.

64. Seligson D, Howard PA, Martin R. Difficulty in removal of certain intramedullary nails. Clin Orthop Relat Res. 1997 Jul(340):202-6.

65. Brown OL, Dirschl DR, Obremskey WT. Incidence of hardware-related pain and its effect on functional outcomes after open reduction and internal fixation of ankle fractures. J Orthop Trauma. 2001 May;15(4):2714.

66. Williams AA, Witten DM, Duester R, Chou LB. The benefits of implant removal from the foot and ankle. J Bone Joint Surg Am. 2012 Jul 18;94(14):1316-20.

67. Georgiadis GM. Percutaneous removal of buried antegrade femoral nails. J Orthop Trauma. 2008 Jan;22(1):52-5.

68. Jago ER, Hindley CJ. The removal of metalwork in children. Injury. 1998 Jul;29(6):439-41. 
Table 1 Arguments in favour and against Implant Removal

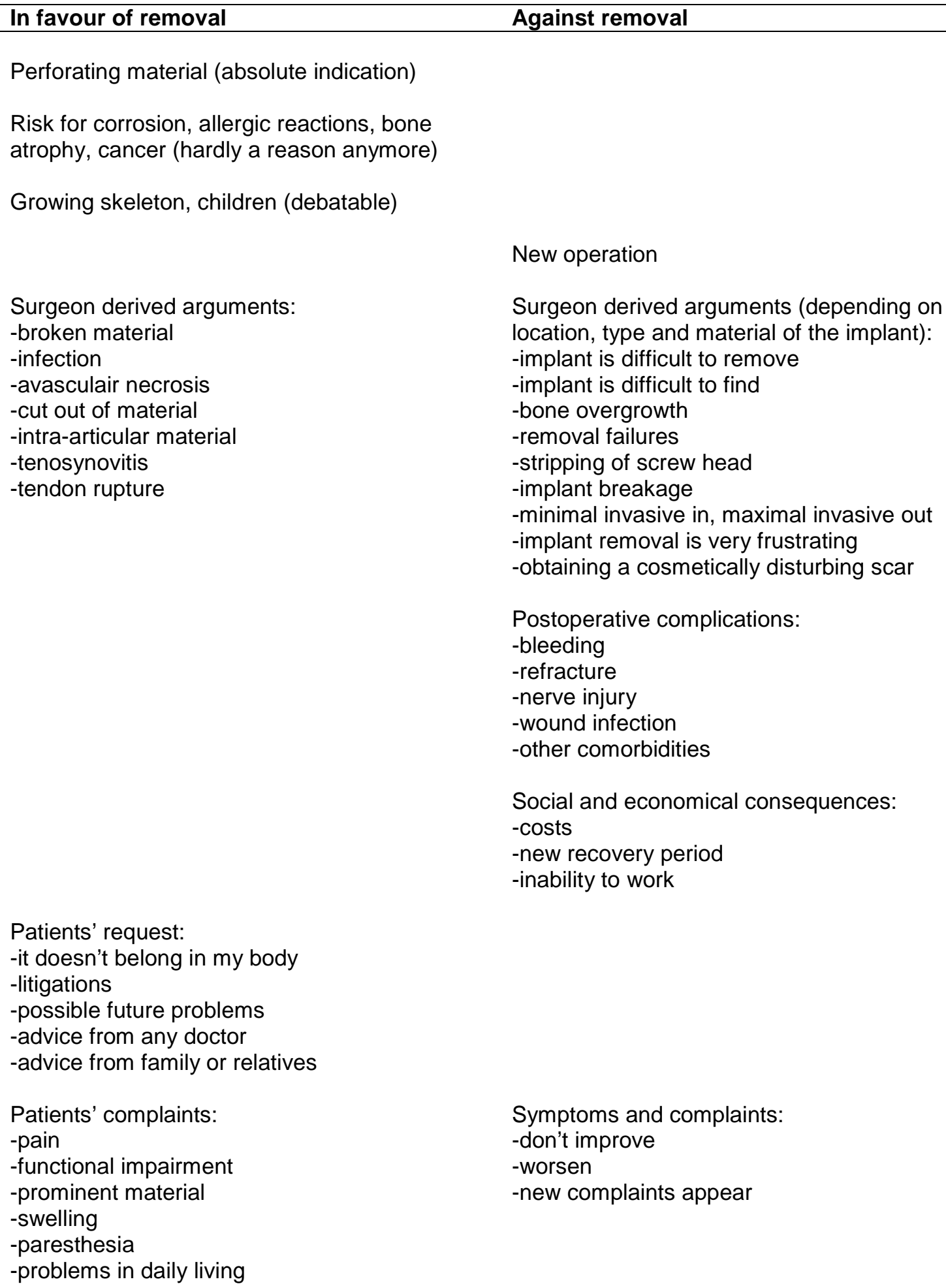

New operation

Surgeon derived arguments (depending on location, type and material of the implant): -implant is difficult to remove -implant is difficult to find -bone overgrowth -removal failures

-stripping of screw head -implant breakage -minimal invasive in, maximal invasive out -implant removal is very frustrating -obtaining a cosmetically disturbing scar

Postoperative complications:

-bleeding

-refracture

-nerve injury

-wound infection

-other comorbidities

Social and economical consequences:

-costs

-new recovery period

-inability to work

Patients' request:

-it doesn't belong in my body

-litigations

-possible future problems

-advice from any doctor

-advice from family or relatives

Patients' complaints:

-pain

-functional impairment

-prominent material

-swelling

-paresthesia

-problems in daily living

Symptoms and complaints:

-don't improve

-worsen

-new complaints appear 
Table 2 Literature on implant removal from the upper extremity

\begin{tabular}{|c|c|c|c|c|c|c|c|}
\hline $\begin{array}{l}\text { Author \& } \\
\text { Journal }\end{array}$ & Study type & $\begin{array}{l}\text { Number of } \\
\text { patients \& } \\
\text { plates }\end{array}$ & $\begin{array}{l}\text { Location } \\
\text { implant }\end{array}$ & Indication for removal & $\begin{array}{l}\text { Time of } \\
\text { implant } \\
\text { removal }\end{array}$ & Complications & Advice \\
\hline $\begin{array}{l}\text { Hidaka } \\
\text { J Bone Joint } \\
\text { Surg Am } 1984 \\
\end{array}$ & Retrospective & $\begin{array}{l}23 \text { patients } \\
32 \text { plates }\end{array}$ & Ulna \& radius & Routinely or complaints & 8-62 months & Refracture $26 \%$ & $\begin{array}{l}\text { Splint or brace for few weeks after } \\
\text { removal } \\
\text { No athletics/ torsional stress } 1 \text { year }\end{array}$ \\
\hline $\begin{array}{l}\text { Deluca } \\
\text { J Bone Joint } \\
\text { Surg Am } 1988\end{array}$ & Retrospective & $\begin{array}{l}37 \text { patients } \\
62 \text { plates }\end{array}$ & Ulna \& radius & Not described & $\begin{array}{l}\text { Not } \\
\text { described }\end{array}$ & $\begin{array}{l}\text { Refracture } 19 \% \\
\text { Nerve injury } 8 \%\end{array}$ & $\begin{array}{l}\text { Radiographic check for } \\
\text { consolidation } \\
\text { Watch out in multi trauma patients } \\
\text { and a failure to achieve initial good } \\
\text { compression }\end{array}$ \\
\hline $\begin{array}{l}\text { Rumball } \\
\text { J Orthop } \\
\text { Trauma } 1990 \\
\end{array}$ & Retrospective & $\begin{array}{l}63 \text { patients } \\
88 \text { plates }\end{array}$ & Ulna \& radius & Routinely & $\begin{array}{l}\text { Average } 15 \\
\text { months }\end{array}$ & $\begin{array}{l}\text { Refracture } 6 \% \\
\text { Neurovasculair } \\
6 \%\end{array}$ & $\begin{array}{l}\text { Removal planned after } 15 \text { months } \\
\text { Use } 3.5 \text { small dynamic compression } \\
\text { plate and thoughtful planning }\end{array}$ \\
\hline $\begin{array}{l}\text { Labosky } \\
\text { J Hand Surg } \\
1990\end{array}$ & Retrospective & $\begin{array}{l}51 \text { patients } \\
80 \text { plates }\end{array}$ & Ulna \& radius & Routinely or complaints & 4-36 months & Refracture $4 \%$ & $\begin{array}{l}\text { Removal should be done because } \\
\text { of risk of metal corrosion and } \\
\text { refracture due to plates. } \\
\text { No specific cast post-operatively } \\
\text { Experienced surgeon }\end{array}$ \\
\hline $\begin{array}{l}\text { Langkamer } \\
\text { J Bone Joint } \\
\text { Surg Br } 1990\end{array}$ & Retrospective & $\begin{array}{l}55 \text { patients } \\
81 \text { plates }\end{array}$ & Ulna \& radius & Routinely or complaints & 5-84 months & $\begin{array}{l}\text { Overall } 40 \% \\
\text { Wound sepsis } 7 \% \\
\text { Poor scar } 9 \% \\
\text { Nerve injury } 29 \% \\
\text { Refracture } 4 \% \\
\end{array}$ & $\begin{array}{l}\text { Removal of forearm plates only in } \\
\text { significant symptomatic patients and } \\
\text { not by a junior surgeon }\end{array}$ \\
\hline $\begin{array}{l}\text { Rosson } \\
\text { J Bone Joint } \\
\text { Surg Br } 1991\end{array}$ & Retrospective & $\begin{array}{l}80 \text { patients } \\
115 \text { plates }\end{array}$ & Ulna \& radius & No strict protocol & 3-39 months & Refracture $5 \%$ & $\begin{array}{l}\text { Removal of plates in the forearm } \\
\text { only in symptomatic patients and at } \\
\text { least after } 18 \text { months }\end{array}$ \\
\hline $\begin{array}{l}\text { Chia } \\
\text { Singapore } \\
\text { Med J } 1996\end{array}$ & Retrospective & $\begin{array}{l}82 \text { patients } \\
128 \text { plates }\end{array}$ & Ulna \& radius & $\begin{array}{l}\text { On indication, symptoms } \\
\text { and complaints }\end{array}$ & 5-84 months & $\begin{array}{l}\text { Overall } 27 \% \\
\text { Wound sepsis } 5 \% \\
\text { Poor scar } 6 \% \\
\text { Nerve injury } 7 \% \\
\text { Refracture } 3 \%\end{array}$ & $\begin{array}{l}\text { Plates should be left in situ and not } \\
\text { removed before } 18 \text { months } \\
\text { Removal by experienced surgeon } \\
\text { After removal restricted physical } \\
\text { activity for } 3 \text { months, especially after } \\
\text { open fractures }\end{array}$ \\
\hline $\begin{array}{l}\text { Gyuricza } \\
\text { J Hand Surg } \\
\text { Am } 2011\end{array}$ & Retrospective & 28 patients & Distal radius & $\begin{array}{l}\text { Tenosynovitis, tendon } \\
\text { rupture, pain, prominent } \\
\text { material }\end{array}$ & 1-52 months & $\begin{array}{l}\text { Stripping screw } \\
\text { head } 7 \%\end{array}$ & $\begin{array}{l}\text { The overall result of removal is } \\
\text { successful in symptomatic patients }\end{array}$ \\
\hline $\begin{array}{l}\text { Lovald } \\
\text { J Trauma } \\
2011\end{array}$ & Retrospective & 751 patients & Humerus & $\begin{array}{l}\text { Nonunion, mechanical } \\
\text { complications, infection }\end{array}$ & $\begin{array}{l}\text { Not } \\
\text { mentioned }\end{array}$ & $\begin{array}{l}\text { Failure removal } \\
10 \%\end{array}$ & $\begin{array}{l}\text { Older people are more likely to } \\
\text { undergo implant removal, self-pay } \\
\text { patients are less likely to have } \\
\text { implant removal }\end{array}$ \\
\hline
\end{tabular}


Table 3a Literature on implant removal from the lower extremity (femur)

\begin{tabular}{|c|c|c|c|c|c|c|c|c|}
\hline $\begin{array}{l}\text { Author \& } \\
\text { Journal }\end{array}$ & Study type & $\begin{array}{l}\text { Number } \\
\text { of } \\
\text { patients }\end{array}$ & $\begin{array}{l}\text { Location \& } \\
\text { type of } \\
\text { implant }\end{array}$ & $\begin{array}{l}\text { Indication for } \\
\text { removal }\end{array}$ & $\begin{array}{l}\text { Time of implant } \\
\text { removal }\end{array}$ & Complications & Outcome & Advice \\
\hline $\begin{array}{l}\text { Brumback } \\
\text { J Bone Joint } \\
\text { Surg } 1992\end{array}$ & Retrospective & 103 & $\begin{array}{l}\text { Femur nail } \\
\text { SS* }^{*}\end{array}$ & $\begin{array}{l}\text { Soft tissue } \\
\text { irritation, patient's } \\
\text { request }\end{array}$ & $\begin{array}{l}14 \text { months } \\
(10-31)\end{array}$ & $\begin{array}{l}1 \text { refracture at the site } \\
\text { of original fracture }\end{array}$ & $\begin{array}{l}\text { Improvement of pain } \\
\text { in all symptomatic } \\
\text { patients }\end{array}$ & $\begin{array}{l}\text { Circumferential healing of } \\
\text { the femoral cortex before } \\
\text { removing } \\
\text { Minimal of } 12 \text { months } \\
\text { before nail removal }\end{array}$ \\
\hline $\begin{array}{l}\text { Boerger } \\
\text { Injury } 1999\end{array}$ & Retrospective & $\begin{array}{l}50 \\
50\end{array}$ & $\begin{array}{l}\text { Femur nail } \\
\text { Tibia nail }\end{array}$ & $\begin{array}{l}\text { Pain hip region } \\
\text { (femur nail), } \\
\text { anterior knee pain } \\
\text { (tibia nail), } \\
\text { infection of the } \\
\text { implant, no } \\
\text { indication found }\end{array}$ & 29 months & $\begin{array}{l}\text { Prolonged operation } \\
\text { time (femur } 2 x \text {, tibia } \\
6 x \text { ) } \\
\text { Wound infection } \\
\text { (femur } 4 x \text {, tibia } 1 x \text { ) } \\
\text { Intra-operative } \\
\text { complication (tibia 3x) }\end{array}$ & $\begin{array}{l}56 \% \text { improvement of } \\
\text { anterior knee pain } \\
4 \text { asymptomatic } \\
\text { patients developed } \\
\text { anterior knee pain } \\
\text { after tibia nail removal }\end{array}$ & $\begin{array}{l}\text { Crutches for an average } \\
\text { of two weeks after } \\
\text { removal }\end{array}$ \\
\hline $\begin{array}{l}\text { Husain } \\
\text { J Orthop } \\
\text { Trauma } 1996\end{array}$ & Retrospective & 45 & $\begin{array}{l}\text { Femur nail } \\
23 \text { titanium } \\
22 \text { SS }\end{array}$ & $\begin{array}{l}\text { Persistent pain, } \\
\text { discomfort, } \\
\text { patients request, } \\
\text { immature skeleton }\end{array}$ & $\begin{array}{l}17 \text { months for } \\
\text { titanium } \\
36 \text { months for } \\
\text { SS }\end{array}$ & $\begin{array}{l}1 \text { suture abscess } \\
1 \text { wound infection }\end{array}$ & $\begin{array}{l}\text { The use of titanium } \\
\text { material is not per se a } \\
\text { risk for difficulty in late } \\
\text { removal of nails }\end{array}$ & $\begin{array}{l}\text { Removal only in } \\
\text { symptomatic patients }\end{array}$ \\
\hline $\begin{array}{l}\text { Dodenhoff } \\
\text { J Bone Joint } \\
\text { Surg } 1997\end{array}$ & Retrospective & 27 & Femur nail & $\begin{array}{l}\text { Pain, heterotopic } \\
\text { ossification }\end{array}$ & 18 months & Not described & $\begin{array}{l}35 \% \text { no pain relief } \\
\text { after removal }\end{array}$ & $\begin{array}{l}\text { Implant removal does not } \\
\text { always cures pain in case } \\
\text { of heterotopic bone } \\
\text { formation }\end{array}$ \\
\hline $\begin{array}{l}\text { Kukla } \\
\text { Acta Chir } \\
\text { Austriaca } \\
2000\end{array}$ & Retrospective & 81 & $\begin{array}{l}\text { DHS** or } \\
\text { gamma nail }\end{array}$ & $\begin{array}{l}\text { Patients request, } \\
\text { deep infection, } \\
\text { avasculair } \\
\text { necrosis, pain, } \\
\text { ipsilateral shaft } \\
\text { fracture }\end{array}$ & 13 months & Not described & Not described & $\begin{array}{l}\text { Removal of DHS or } \\
\text { gamma nail in patients < } \\
60 \text { years to avoid } \\
\text { associated complications } \\
\text { like shaft fracture distal to } \\
\text { the implant }\end{array}$ \\
\hline $\begin{array}{l}\text { Toms } \\
\text { Injury } 2002\end{array}$ & Retrospective & 34 & Femur nail & $\begin{array}{l}\text { Persistent pain, } \\
\text { Prominent } \\
\text { material, prior to } \\
\text { hip replacement, } \\
\text { No specific reason }\end{array}$ & Not described & Not described & $\begin{array}{l}\text { Improvement of } \\
\text { physical and mental } \\
\text { components }\end{array}$ & $\begin{array}{l}\text { Nail removal in } \\
\text { symptomatic patients }\end{array}$ \\
\hline $\begin{array}{l}\text { Gösling } \\
\text { Clin Orthop } \\
2004\end{array}$ & Retrospective & 164 & Femur nail & $\begin{array}{l}\text { Routine removal, } \\
\text { advice surgeon, } \\
\text { patient request, } \\
\text { pain, restriction of } \\
\text { motion }\end{array}$ & $\begin{array}{l}27 \text { months } \\
(8-82)\end{array}$ & $\begin{array}{l}\text { Breakage of the nail or } \\
\text { screws, post-operative } \\
\text { hematoma, seroma, }\end{array}$ & $\begin{array}{l}78 \% \text { improvement in } \\
\text { symptomatic patients, } \\
16 \% \text { no change, } \\
20 \% \text { of the previously } \\
\text { asymptomatic patients } \\
\text { became symptomatic, } \\
46 \% \text { no benefit }\end{array}$ & $\begin{array}{l}\text { Only nail removal in } \\
\text { symptomatic patients } \\
\text { Inform patients about soft } \\
\text { tissue problems, } \\
\text { prolonged hospitalization, } \\
\text { reoperation or worsening } \\
\text { of symptoms } \\
\end{array}$ \\
\hline $\begin{array}{l}\text { Hui } \\
\text { Can J Surg } \\
2007\end{array}$ & Retrospective & 15 & Femur nail & Pain or irritation & Not described & Not described & $\begin{array}{l}\text { Litigants more often } \\
\text { require removal }\end{array}$ & $\begin{array}{l}\text { Routine removal in } \\
\text { asymptomatic patients is } \\
\text { not recommended }\end{array}$ \\
\hline
\end{tabular}


Table 3b Literature on implant removal from the lower extremity (tibia)

\begin{tabular}{|c|c|c|c|c|c|c|c|c|}
\hline $\begin{array}{l}\text { Author \& } \\
\text { Journal }\end{array}$ & Study type & $\begin{array}{l}\text { Number } \\
\text { of } \\
\text { patients }\end{array}$ & $\begin{array}{l}\text { Location \& } \\
\text { type of } \\
\text { implant }\end{array}$ & $\begin{array}{l}\text { Indication for } \\
\text { removal }\end{array}$ & $\begin{array}{l}\text { Time of implant } \\
\text { removal }\end{array}$ & Complications & Outcome & Advice \\
\hline $\begin{array}{l}\text { Sidky } \\
\text { Can J Surg } \\
2008\end{array}$ & Retrospective & 29 & Tibia nail & $\begin{array}{l}\text { Pain, prominent } \\
\text { material }\end{array}$ & $\begin{array}{l}25 \text { months } \\
(5-77)\end{array}$ & Not described & $72 \%$ improvement & $\begin{array}{l}\text { Gender and litigation } \\
\text { status influence the rate } \\
\text { of nail removal }\end{array}$ \\
\hline $\begin{array}{l}\text { Gösling } \\
\text { Chirurg } 2005\end{array}$ & Retrospective & 69 & Tibia nail & $\begin{array}{l}\text { Pain \& symptoms } \\
59 \% \text {, } \\
\text { Asymptomatic } \\
41 \%\end{array}$ & $\begin{array}{l}21 \text { months } \\
(13-43)\end{array}$ & $\begin{array}{l}7 \% \text { knee punction } \\
\text { because of fluid } \\
1 \% \text { left screw in ankle } \\
\text { joint }\end{array}$ & $\begin{array}{l}73 \% \text { improvement } \\
8 \% \text { aggravation of } \\
\text { complaints in the } \\
\text { symptomatic group, } \\
17 \% \text { long term } \\
\text { complaints in the } \\
\text { asymptomatic group }\end{array}$ & $\begin{array}{l}\text { Routine removal of tibial } \\
\text { nails should be discussed } \\
\text { critically in asymptomatic } \\
\text { patients }\end{array}$ \\
\hline $\begin{array}{l}\text { Keating } \\
\text { J Orthop } \\
\text { Trauma } 1997\end{array}$ & Retrospective & 49 & Tibia nail & Knee pain & Not described & Not described & $\begin{array}{l}44 \% \text { complete pain } \\
\text { relief }\end{array}$ & $\begin{array}{l}\text { Nail removal for patients } \\
\text { with a painful knee }\end{array}$ \\
\hline $\begin{array}{l}\text { Karladani } \\
\text { Acta Orthop } \\
2007\end{array}$ & Retrospective & 71 & Tibia nail & $\begin{array}{l}\text { Anterior knee pain, } \\
\text { pain elsewhere, } \\
\text { infection, } \\
\text { prominent } \\
\text { material, patient } \\
\text { request }\end{array}$ & $\begin{array}{l}17 \text { months } \\
(4-50)\end{array}$ & Not described & $\begin{array}{l}55 \% \text { reduced pain, } \\
20 \% \text { unaltered pain, } \\
25 \% \text { elevated pain }\end{array}$ & $\begin{array}{l}\text { The outcome after tibia } \\
\text { nail removal to alleviate } \\
\text { pain is generally poor }\end{array}$ \\
\hline $\begin{array}{l}\text { Im } \\
\text { Int Orthop } \\
2003\end{array}$ & Retrospective & 35 & Tibia nail & $\begin{array}{l}\text { Expected } \\
\text { difficulties in } \\
\text { treating possible } \\
\text { new fractures }<50 \\
\text { years }\end{array}$ & $\begin{array}{l}26 \text { months } \\
(13-61)\end{array}$ & $\begin{array}{l}3 \text { iatrogenic fracture } \\
\text { because of } \\
\text { considerable force } \\
\text { needed to remove the } \\
\text { nail } \\
2 \text { removal failures }\end{array}$ & Not described & $\begin{array}{l}\text { Anticipate on the type of } \\
\text { nail when removal is } \\
\text { being considered }\end{array}$ \\
\hline
\end{tabular}

*SS = stainless steel, **DHS = dynamic hip screw 